\title{
Immunogenicity and efficacy of oral vaccines in developing countries: lessons from a live cholera vaccine
}

\author{
Myron M Levine*
}

\begin{abstract}
Oral vaccines, whether living or non-living, viral or bacterial, elicit diminished immune responses or have lower efficacy in developing countries than in developed countries. Here I describe studies with a live oral cholera vaccine that include older children no longer deriving immune support from breast milk or maternal antibodies and that identify some of the factors accounting for the lower immunogenicity, as well as suggesting counter-measures that may enhance the effectiveness of oral immunization in developing countries. The fundamental breakthrough is likely to require reversing effects of the 'environmental enteropathy' that is often present in children living in fecally contaminated, impoverished environments.
\end{abstract}

Vaccines represent the epitome of a preventive strategy to control disease $[1,2]$. In the individual, they confer direct protection and, if high enough immunization coverage of a population is achieved, unimmunized people may also be protected, indirectly, through 'herd immunity' [3,4]. The strategic use of some vaccines, such as measles and polio vaccines, has interrupted indigenous transmission of those diseases in entire regions of the globe [5-8]. And one disease, smallpox, has been completely eradicated from the human population through the epidemiologically sound use of smallpox vaccine $[9,10]$.

In developing countries, where two-thirds of the world's population live, infectious diseases cause most of the mortality among children under 5 years of age [11] and constitute major health problems in older children

\footnotetext{
*Correspondence: mlevine@medicine.umaryland.edu Center for Vaccine Development, University of Maryland School of Medicine, Baltimore, MD 21201, USA
}

and adults. Vaccines are among the most promising interventions to diminish the burden of specific infections in populations in developing countries [12-15].

\section{The special advantages of oral vaccines}

Oral vaccines are particularly attractive for immunizing populations in developing countries for several reasons. First, contaminated needles and syringes are major problems both for health workers and for environmental safety in many developing countries where there is a high prevalence of HIV and hepatitis B and C [16-18]. Because they obviate the need for needles and syringes, oral vaccines allow less qualified health workers to carry out immunization. Second, the simple logistics of oral vaccines are highly compatible with mass immunization campaigns $[19,20]$. Lastly, in most societies both adults and children generally prefer an oral vaccine to a parenteral injection.

Despite the attractions of oral vaccines for developing countries, many oral vaccines, both live and non-living, have proven to be less immunogenic or less protective when administered to infants, children or adults living in low socioeconomic conditions in less-developed countries than they are when used in industrialized countries (Table 1). Thus, there is a poorly understood 'intestinal barrier' to successful immunization of people in less developed countries who receive oral vaccines. Here, I review this phenomenon, provide examples and possible explanations, and offer suggestions for establishing the basis of the phenomenon.

\section{Immune responses to oral vaccines in developing countries}

A prototype: Sabin oral polio vaccine

The prototype oral vaccine is the Sabin attenuated strains trivalent polio vaccine (tOPV), which eliminated transmission of wild-type polioviruses in the Americas [21], the Western Pacific [22] and Europe [22] and has been the linchpin of the Global Polio Eradication Initiative 
Table 1. Oral vaccines associated with diminished immunogenicity or efficacy in developing country populations

\begin{tabular}{|c|c|c|c|}
\hline Oral vaccine & $\begin{array}{l}\text { Target ages at which diminished } \\
\text { immunogenicity or protection } \\
\text { was observed }\end{array}$ & $\begin{array}{l}\text { Geographic locations } \\
\text { where observed }\end{array}$ & References \\
\hline Sabin polio vaccine strains & $\begin{array}{l}\text { Infants, toddlers, preschool children, } \\
\text { school-age children }\end{array}$ & India, sub-Saharan Africa & {$[25-33]$} \\
\hline RIT 4237 rotavirus & Infants & Gambia & [36] \\
\hline $\begin{array}{l}\text { Rotashield rotavirus vaccine } \\
\text { ( } 10^{4} \text { plaque forming unit dosage) }\end{array}$ & Infants & Brazil and Peru & {$[37,125]$} \\
\hline Rotarix attenuated rotavirus & Infants & Malawi, South Africa, Bangladesh & [38] \\
\hline Rotateq pentavalent attenuated rotavirus & Infants & Ghana, Kenya, Mali & [39] \\
\hline MMU18006 (monovalent Rhesus rotavirus strain) & Infants & Pakistan & {$[40]$} \\
\hline CVD 103-HgR live cholera strain & 24-59 months; $5-9$ years; adults & Indonesia, Thailand, Peru, Ecuador & {$[41-43,64]$} \\
\hline $\begin{array}{l}\text { Dukoral non-living cholera vaccine } \\
\text { (killed V. cholerae O1 plus B subunit) }\end{array}$ & $1-12$ years & Nicaragua & [45] \\
\hline SC602 attenuated Shigella flexneri strain & Toddlers and school age children & Bangladesh & {$[46,47]$} \\
\hline
\end{tabular}

$[23,24]$. Of the three poliovirus serotypes (types 1 to 3 ), tOPV has interrupted transmission of type 2 poliovirus globally since 1999 .

Despite the remarkable milestones of disease control achieved with tOPV, it has been recognized since the 1960 s that tOPV seems to be poorly and inconsistently immunogenic in some developing country populations [25-31]. Diminished immunogenicity has been a particularly vexing problem in the states of Uttar Pradesh and Bihar in India [32,33], from which wild-type polioviruses have been disseminated to other states in India and elsewhere in South Asia. By late 2005, the average child under 5 years of age in Bihar and Uttar Pradesh had received about 15 doses of OPV compared with about 10 doses for children of the same age elsewhere in India [34]. However, because of diminished immunogenicity, only an estimated $71 \%$ of children under age 5 years in these two states were successfully immunized against polio, compared with $85 \%$ of children elsewhere in India [34]. Diminished immune responses in children in these areas of India are correlated with poor sanitation, a high prevalence of diarrheal illness at the time of vaccination, competing enteric viruses and competition of type 2 with types 1 and 3 vaccine viruses [34]. Type 2 Sabin OPV strain colonizes the intestine better and is considerably more immunogenic than types 1 or 3 . For this reason tOPV is formulated to contain less type 2 virus than the other two serotypes (ratio of $10^{6}: 10^{5}: 10^{5.8}$ infectious units per dose) [35] to try and mute its dominance. Nevertheless, in some developing country populations, including Uttar Pradesh and Bihar, it was necessary to change from use of tOPV in mass campaigns to the selective use of monovalent type 1 and 3 vaccines or to bivalent type $1+3$ vaccine to improve immune responses to these serotypes and to interrupt transmission $[34,35]$.

\section{Other oral vaccines with diminished immunogenicity or efficacy}

Table 1 lists various oral vaccines for which data from clinical trials have demonstrated either a diminished immune response or lower efficacy in developing countries than in industrialized country populations. Besides Sabin polio vaccine [25-31], these oral vaccines include rotavirus vaccines [36-40], CVD 103-HgR live cholera vaccine [41-44], B subunit-inactivated Vibrio cholerae whole cell combination vaccine [45] and SC602 live Shigella flexneri $2 \mathrm{a}$ vaccine $[46,47]$. Thus, the oral vaccines implicated include both viral and bacterial and both live and nonliving vaccines. Moreover, the phenomenon has been observed in all age groups, from young infants to adults. To maximize the protective effects that can be achieved with oral vaccines in developing countries, it will be important to understand why immune responses and efficacy tend to be lower in such target populations than in populations in industrialized countries.

\section{Oral vaccines in young infants}

Some common factors probably contribute to lowering the immunogenicity and efficacy of live oral vaccines among people of all ages in developing countries. However, there are special confounding factors in the case of young infants. In that age group, there is likely to be some level of immunity due to maternal serum IgG antibodies transferred in utero, and to breast milk, which contains maternal secretory immunoglobulin A (sIgA) antibodies [48], immune cells and non-specific protective factors, such as lactoferrin [49,50] and oligosaccharides [51]. These both provide protection against pathogens and modulate responses to vaccines.

Early studies with tOPV, RIT 4237 rotavirus vaccine [36], tetravalent rhesus reassortant rotavirus vaccine at 
the $10^{4}$ plaque forming unit dosage level [52] and other candidate rotavirus vaccine strains [40] indicated a barrier to oral immunization. Two new rotavirus vaccines, Rotarix, the monovalent human G1P [8] strain attenuated by multiple passages in tissue culture [53], and Rotateq, a pentavalent vaccine based on reassortant bovine rotavirus expressing human rotavirus surface proteins G1 to 4 and P [8] [54], have been shown to be safe, immunogenic and highly protective against severe rotavirus gastroenteritis in large-scale, placebo-controlled efficacy trials in infants in North America, Europe and South America. However, when tested in efficacy trials in Africa and Asia, these two vaccines showed much lower efficacy $[38,39]$. The level of efficacy tended to correlate with the level of development of the population in which the vaccines were tested. Although this may reflect environmental influences such as competing enteric viral, bacterial or protozoan infections, it is likely that higher titers of breast milk IgA and maternally derived serum IgG antibodies against rotavirus also played a role in the places where vaccine efficacy was lowest.

\section{Oral vaccines in older age groups}

Various oral vaccines have demonstrated diminished immunogenicity or efficacy in older age groups, including in pre-school and school-age children and adults. By focusing on vaccines in these age groups, it is possible to identify and study environmental and host factors without the confounding effects of breast milk and maternal antibodies. The vaccine that has been most intensively studied for these factors is live oral cholera vaccine strain CVD 103-HgR, a genetically engineered vaccine derived from a wild-type $V$. cholerae $\mathrm{O} 1$ classical biotype, Inaba serotype strain. In this vaccine, $94 \%$ of the gene encoding the enzymatically active A subunit of cholera toxin has been deleted and a gene encoding mercury ion resistance inserted into the hemolysin A locus as an indelible marker [55-57]. Our experience, and that of other groups, with CVD 103-HgR is reviewed below to illustrate how factors associated with diminished immunogenicity to oral vaccines in developing country populations can be identified and examined in order to devise ways to overcome the barrier.

\section{The CVD 103-HgR live oral cholera vaccine as a paradigm}

Two O serogroups of $V$. cholerae, $\mathrm{O} 1$ and $\mathrm{O} 139$, can cause epidemics of cholera gravis. $V$. cholerae $\mathrm{O} 1$ is by far the more important as O139 infections are found in just a few areas of Asia (where they are responsible for only a few percent of cases) and O139 has not been reported from Africa. Two biotypes of $V$. cholerae $\mathrm{O} 1$ exist, El Tor and classical, although presently only El Tor strains are prevalent. Recently, highly virulent El Tor strains have emerged that produce classical biotype cholera enterotoxin. Within each biotype of $\mathrm{O} 1$ are found two main serotypes, Inaba and Ogawa. For a cholera vaccine to be a useful public health tool, it must protect against both serotypes and biotypes. In North American adults, a single oral dose of about $5 \times 10^{8}$ colony forming units (cfu) of CVD 103-HgR elicits significant (four-fold or greater) rises in serum vibriocidal antibody (that is, seroconversion) in over $90 \%$ of those vaccinated $[56,58]$ and vaccine organisms are excreted by about $25 \%[56,58]$. A single dose of CVD 103-HgR significantly protects North Americans against cholera caused by $V$. cholerae $\mathrm{O} 1$ of either classical or El Tor biotype and either Inaba or Ogawa serotype [56,59-61].

The first study in a developing country examining the safety and immunogenicity of CVD 103-HgR was carried out among young adult students on a Research Isolation Ward at Mahidol University, Bangkok, Thailand [62], with immunogenicity results closely resembling those seen in healthy North Americans and Europeans. Therefore, bolstered by the promising results of this (small) trial, a pediatric study was initiated in children 5 to 9 years of age living in a squalid, cholera-endemic slum in North Jakarta, Indonesia [41] (Figure 1a). In these children, the $5 \times 10^{8} \mathrm{cfu}$ dose of CVD 103-HgR that had been so highly immunogenic in North American $[56,58]$ and Swiss [63] adults and higher socioeconomic level Thai university students [62] elicited significant increases in serum vibriocidal antibody in only $16 \%$ of the 5 - to 9-year-old Indonesian children living in poverty [41]. This was the first demonstration that diminished immunogenicity in developing country situations could also be encountered with oral bacterial vaccines [41], as had been recognized for many years with oral viral vaccines.

Fortunately, by administering a tenfold higher dose of CVD 103-HgR $\left(5 \times 10^{9} \mathrm{cfu}\right)$ to children 5 to 9 years of age in North Jakarta, it was possible to achieve a high rate of seroconversion [41]. Moreover, the few non-responders were shown to be children who had high baseline titers of serum vibriocidal antibody and therefore were apparently already immune to cholera. Results with children 2 to 4 years of age living in the same area were similar [64]. In studies with both adults and children, those who did not seroconvert had a significantly higher baseline vibriocidal titer than those who did seroconvert [41-43,64], indicating that such individuals are already immune and their serum titers are not typically boosted by vaccination.

It is worth noting that oral vaccines are expected to elicit locally produced intestinal antibodies and tests of serum antibodies do not detect these local antibodies. It is thus conceivable that intestinal antibodies may have increased in these studies. Indeed, it has long been surmised that rises in serum vibriocidal antibodies serve as a proxy for the elicitation of immune responses in the 


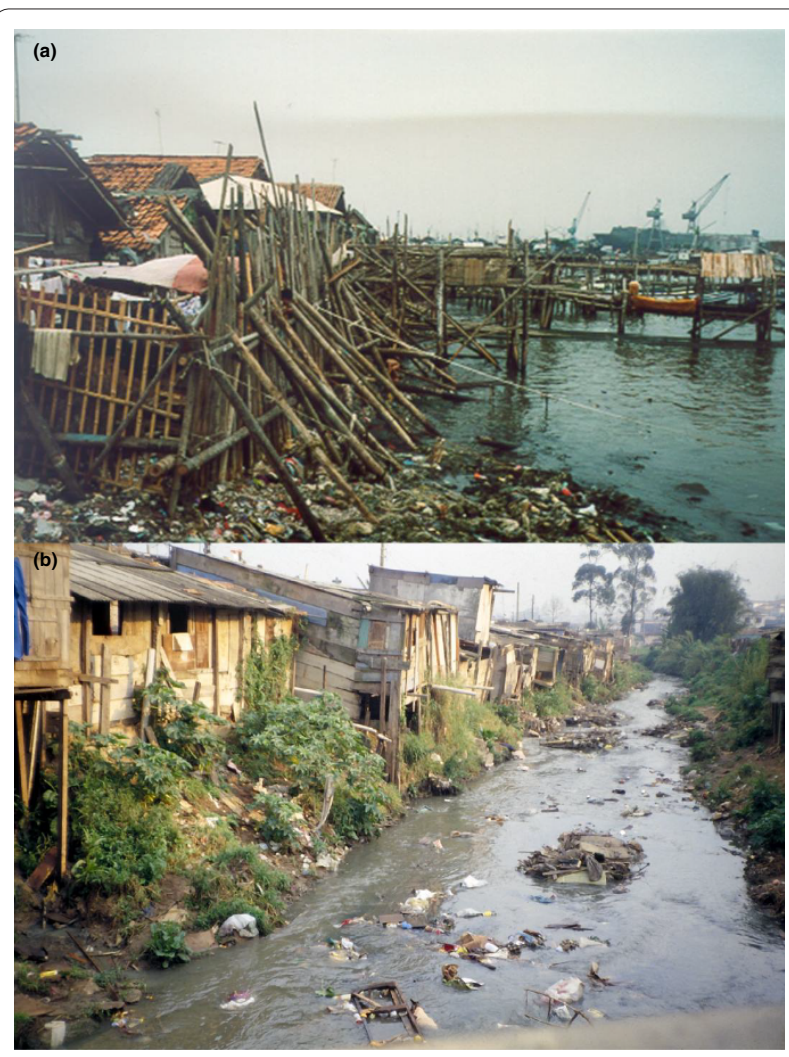

Figure 1. Cholera-endemic living conditions. (a) Conditions of ramshackle housing, poor sanitation and widespread fecal contamination prevalent in North Jakarta in the early 1990s when phase 2 pediatric clinical trials with CVD 103-HgR live oral cholera vaccine were carried out. (b) Similar conditions of inadequate housing, lack of sanitation and fecally contaminated surface waters in a favella (periurban slum) in São Paulo, Brazil of the type in which environmental enteropathy was first described by Fagundes Neto. Photograph kindly provided by Ulysses Fagundes Neto, Universidade Federal de São Paulo.

small intestine. It is also possible that some individuals may have baseline intestinal immunity not reflected by an elevated serum vibriocidal titer.

A series of additional immunogenicity studies with CVD 103-HgR were undertaken in Asia [42], South America [43,65-69] (after the El Tor pandemic of cholera reached that continent in 1991) and Africa [70]. From this composite of clinical trials, we identified several factors that modulated the magnitude of the vibriocidal antibody response. The first of these is prior exposure to $V$. cholerae $\mathrm{O} 1$, resulting in high baseline vibriocidal antibody titers: titers are not usually boosted in individuals with high baseline titers [41-43,64]. The second factor is blood group $\mathrm{O}$ : people with blood group $\mathrm{O}$ (a well recognized host risk factor for development of cholera gravis $[71,72])$ mount stronger serum vibriocidal responses [66], especially if immunologically naïve - that is, with no prior exposure to $V$. cholerae O1. The third factor is socioeconomic level: populations in underprivileged conditions show lower antibody titers, independent of blood group or prior contact with $V$. cholerae O1 $[42,43]$. The fourth factor is small bowel bacterial overgrowth (SBBO) [44] that often accompanies environmental enteropathy (see below) [73,74], which in turn is related to living in poverty-associated fecally contaminated conditions. The fifth factor is heavy infection with intestinal helminths $[75,76]$. The sixth factor is HIV status: although the rates of seroconversion are not significantly different, the antibody titers of HIV-positive individuals are significantly lower than those of HIVnegative individuals [70].

To achieve high seroconversion rates of vibriocidal antibody in Peruvian and Thai adults living in underprivileged conditions, as with Indonesian children living in poverty, it was necessary to give a tenfold higher dose $\left(5 \times 10^{9} \mathrm{cfu}\right)$ of CVD 103-HgR [41-43] than the dosage level $\left(5 \times 10^{8} \mathrm{cfu}\right)$ that was consistently immunogenic in North Americans and Europeans [56,58]. This $10^{9} \mathrm{cfu}$ dosage level was also well tolerated and immunogenic in pre-school children [64,67], toddlers [68] and infants as young as 3 months of age [68].

\section{The role of environmental enteropathy and small bowel bacterial overgrowth}

The proximal small intestines of healthy children and adults who live in relatively pristine environments in industrialized countries show only modest bacterial loads, whether measured by aerobic and anaerobic culture or by molecular techniques based on analysis of $16 \mathrm{~S}$ rDNA sequencing of DNA from appropriate clinical specimens $[77,78]$. Common known bacterial genera identified include Streptococcus, Veillonella, Neisseria, Gemella, Rothia and Hemophilus; in contrast, fecal genera, such as are found in the colon or terminal ileum (where microbiota densities are enormous), are uncommon. Duodenal biopsies show that the mucosa of healthy children is characterized histologically by the presence of long, finger-like villi, ample columnar epithelial cells, a crypt to villus ratio of $1: 3$ or 1:4, less than 25 intraepithelial lymphocytes per 100 columnar cells and only a moderate number of mononuclear cells in the lamina propria (Figure 2). In contrast, the gut of children living in poverty in developing countries often reflects their continual exposure to fecally contaminated environments, and many such children have SBBO and 'environmental enteropathy' [73,74,79-81].

The term environmental enteropathy was coined by Fagundes Neto $[73,74,80]$ to describe a syndrome that includes non-specific histopathological and functional changes of the small intestine in children of poor families living in conditions lacking basic sanitary facilities and chronically exposed to fecal contamination (Figure 1b). 


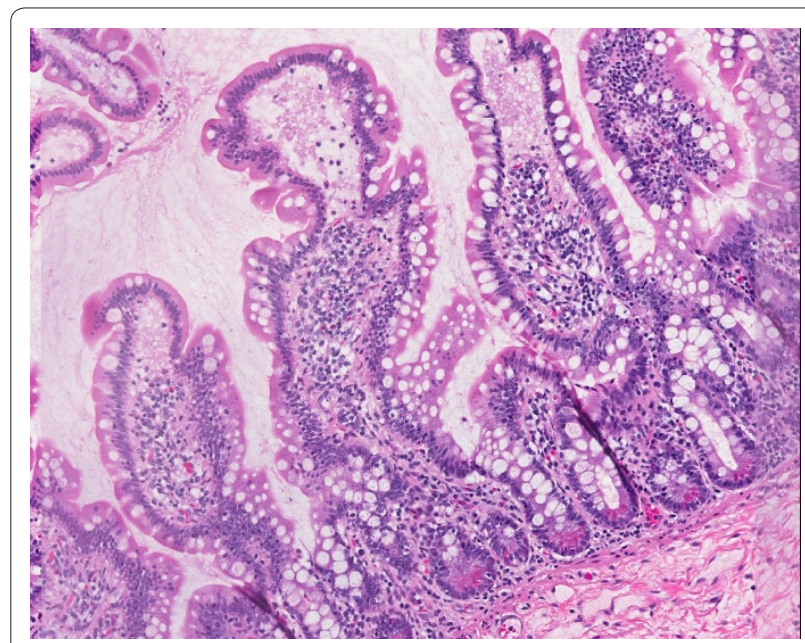

Figure 2. Normal intestinal mucosa. Biopsy of the second portion of the duodenum of an 8-year-old US child showing normal histology of the intestinal mucosa. Long, finger-like villi and relatively shallow crypts are evident. The villi are populated with columnar epithelial cells (enterocytes) that have brush borders containing enzymes for digestion and absorption; mucus-producing goblet cells are interspersed among the enterocytes. Less than 20 intraepithelial lymphocytes per 100 enterocytes are present. Photomicrograph kindly provided by Steven Czinn, University of Maryland Medical Center.

The prominent histopathological features of environmental enteropathy include blunted villi, abnormal crypt to villus ratio, an increased number of intraepithelial lymphocytes and a marked increase of lymphocytes and plasmacytes in the lamina propria (Figure 3a,b). A key feature of environmental enteropathy is the presence of SBBO that includes fecal bacterial species usually restricted to the terminal ileum and colon. Another salient feature of environmental enteropathy is its disappearance over time following the individual's transfer to a clean environment characterized by improved food hygiene and modern sanitation [80]. Environmental enteropathy is similar (and perhaps identical) to the syndrome of 'tropical enteropathy' described by Lindenbaum et al. [82] in US Peace Corps volunteers who lived among indigenous populations for about two or more years, often in conditions characterized by heavy fecal contamination. The intestinal lesions observed in most of these young adults also slowly returned to normal several months after the volunteers returned to the USA [82].

The presence of SBBO can be detected by having fasting children ingest the disaccharide lactulose and detecting $\mathrm{H}_{2}$ in expired breath by gas chromatography at various time points; measurements are typically made at baseline and 15, 30, 40, 60, 90 and 120 minutes after ingestion of the lactulose $[44,80,83]$. Human intestinal enzymes cannot cleave lactulose but bacterial enzymes can. Therefore, the detection of $\mathrm{H}_{2}$ in 'small bowel'

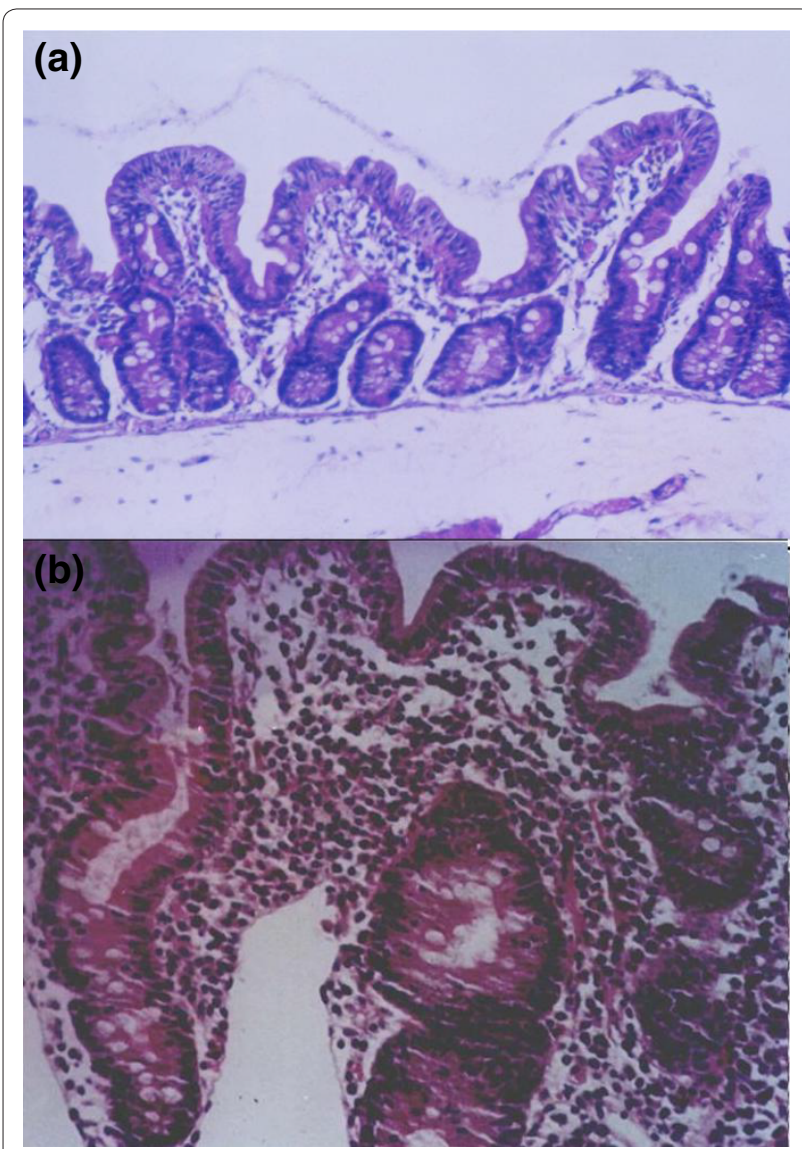

Figure 3. Intestinal mucosa showing environmental enteropathy. (a) Biopsy of the distal duodenum of a 36-month old Brazilian child with environmental enteropathy. Moderate villous atrophy is seen with blunted, flat villi and enterocytes that seem somewhat cuboidal rather than columnar. Elongated crypts can be seen, which result in an abnormal crypt to villus ratio. Most prominent is the striking increase in the number of lymphocytes and plasmacytes present in the lamina propria. (b) Biopsy of the distal duodenum of another Brazilian pre-school age child with environmental enteropathy. The changes are as described for (a) but the villous blunting and hypercellularity within the lamina propria are even more prominent. Photomicrographs kindly provided by Ulysses Fagundes Neto, Universidade Federal de São Paulo.

specimens - that is, those taken 15 or 30 minutes after lactulose ingestion -indicates SBBO [44,80,83]. The advantage of the lactulose breath $\mathrm{H}_{2}$ test is that it is amenable to field studies involving hundreds of children $[44,80,83]$.

When the relationship between SBBO and vibriocidal response to CVD 103- $\mathrm{HgR}$ was investigated in 202 fasting Chilean schoolchildren aged 5 to 9 years who had lactulose breath $\mathrm{H}_{2}$ tests one day before ingesting CVD 103-HgR [44], florid small bowel overgrowth was observed in 10 out of 178 analyzable children (5.6\%), and logistic regression analysis showed that increased peak breath $\mathrm{H}_{2}$ at 'small bowel' time points was associated with 
diminished vibriocidal antibody seroconversion, as was the interaction of peak breath $\mathrm{H}_{2}$ and weight $(P=0.02)$ [44].

SBBO could blunt the immune response to CVD 103-HgR by the production of short chain fatty acids (such as butyric and propionic acids) [84] or other small molecules [85] that directly inhibit the $V$. cholerae $\mathrm{O} 1$ vaccine, thereby markedly decreasing the actual dose of vaccine organisms. Immune responses to cross-reacting surface antigens of intestinal flora may also blunt the vibriocidal response to CVD 103-HgR. Alternatively, the effect may be indirect. Individuals with SBBO typically have abnormal intestinal architecture [73,74] and increased lymphocytes and plasmacytes in the mucosa $[73,74]$, perhaps with activated T cells [86]. One possible explanation is that under conditions of repetitive exposure to fecal contamination, the innate immune system of the child's gut is maximally activated and in a proinflammatory state. This may constitute an important non-specific defense in the proximal small intestine, rendering it generally hostile to incoming bacterial (and viral and protozoal) pathogens. Indeed, this may be what allows many children to survive repeated exposures to enteric pathogens. By extrapolation, attenuated bacterial or viral oral vaccines must also face this hostile, innate immune system-activated ecologic niche when they reach the proximal small intestine, resulting in inhibition of the vaccine organisms and poor induction of specific adaptive immune responses. Live vaccines might then, instead of activating the innate immune system to enhance adaptive immune responses (as would happen in an industrialized country gut), be destroyed by an already highly activated innate immune response.

Supporting this hypothesis is the observation that although people in developing countries show moderate or high rates of seroconversion following ingestion of the $10^{9} \mathrm{cfu}$ dosage level of CVD 103-HgR, they also show significantly lower rates of excretion of the vaccine strain $[41,43,64,67,68]$. It is increasingly recognized that normal gut homeostasis (including gut immunity) involves 'crosstalk' among the microbiota present in the outer layer of the mucus biofilm covering the mucosa, enterocytes and cells of the immune system [87-91].

An alternative explanation for the decreased immune responses is that the mononuclear cell hypercellularity observed in the mucosa of patients with environmental enteropathy may indicate altered regulatory $\mathrm{T}$ cell and dendritic cell function that contributes to dampening of immune responses $[81,92,93]$. It is possible that environmental enteropathy modifies the proximal small bowel ecology so much that it begins to resemble the colon not only in its microbiota but in the immunological functioning of its mucosa (immune structures commonly form in chronically infected mucosa). Collectively, these ideas may be considered the obverse of the 'hygiene hypothesis' - the widely popularized notion that the increasing prevalence of allergies in industrialized countries reflects a failure to develop the normal regulatory balance of the adaptive immune response when exposure to environmental pathogens is limited [94-96].

Further evidence of a role for intestinal infection in the diminished vibriocidal antibody response to the CVD 103-HgR vaccine has been gathered in studies on school age children in rural Ecuador with documented heavy helminthic (Ascaris lumbricoides) infection [75,76]. These children were randomly allocated to receive two courses of an anti-helminthic (albendazole) or placebo and were then immunized with a single $5 \times 10^{8} \mathrm{cfu}$ dose of CVD 103-HgR [75]. For children of blood group O, there was no difference in the vibriocidal responses observed in the albendazole versus the placebo groups. However, for children of non-O blood groups, those treated with albendazole had a significantly higher vibriocidal antibody response than those given placebo.

\section{Extrapolating to other oral vaccines}

Some of the factors that seem to contribute to the diminished immunogenicity of CVD 103-HgR may be relevant to other oral live vaccines. Live oral Shigella flexneri 2a candidate SC602 was reactogenic in North American volunteers when $\geq 10^{6}$ cfu were ingested [97]. However, ingestion of a lower, better tolerated dose $\left(10^{4} \mathrm{cfu}\right)$ was followed by heavy excretion, strong immune responses and protection against experimental challenge with wild-type S. flexneri 2a [97]. In contrast, when tested in a phase 1 trial in Bangladeshi toddlers, neither vaccine excretion nor immune responses were observed following ingestion of $10^{4}, 10^{5}$ or $10^{6} \mathrm{cfu}$ of SC602 [47].

Licensed live oral typhoid vaccine Ty21a may be a notable exception. This live oral vaccine does not elicit strong (that is, high titer) serum antibody responses $[98,99]$ but does stimulate intestinal IgA antibodies [100] as well as robust B [101] and T cell-mediated [102-105] immune responses, and appropriate formulations and immunization schedules of Ty21a have conferred significant protection on school-age children for up to 7 years in large-scale, randomized, controlled efficacy trials in Egypt [106], Chile [107-110] and Indonesia [111]. This may be a function of the way Salmonella Typhi interacts with the small intestinal mucosa, as this organism effectively targets the $M$ cells that overlie gutassociated lymphoid tissue $[112,113]$ and is then readily taken up by the underlying dendritic cells and macrophages. Thus, Ty21a easily and rapidly gains access to inductive sites of the immune system. This may hold true for several markedly more immunogenic modern recombinant $S$. Typhi single-dose vaccine candidates that are in development [114-117]. 


\section{A way forward}

Now that the poor response of many people in developing countries to a variety of oral vaccines has been documented and widely recognized, a consensus is emerging that action should be initiated to study the phenomenon, with a view to counteracting the factors responsible for the intestinal barrier [118]. With respect to the role of SBBO and the alterations of the intestinal mucosa that characterize environmental enteropathy, there is much to be done. A first step should be to separate any direct inhibitory role of the bacterial flora itself, whether in mucus-associated biofilm or in the lumen, from the broader defects that may be consequent on the altered architecture and function of the intestinal mucosa. A controlled trial should be undertaken to determine whether temporarily eliminating SBBO with oral antibiotics before oral immunization enhances immune responses to the vaccine [119]. If this has a positive effect, then non-antibiotic interventions (such as competing probiotic bacteria) should be studied.

Giardia infections are highly prevalent among children in developing countries but are increasingly recognized not to be associated with either diarrhea or adverse nutritional consequences [120]. Nevertheless, Giardia may have an impact on mucosal integrity and function that may diminish responses to oral vaccines. Thus, I would advocate a randomized, placebo-controlled trial in which half the participants receive metronidazole to eradicate Giardia before oral vaccination.

If eliminating SBBO with antibiotics or Giardia with metronidazole has no impact, then ways should be explored to repair the integrity and function of the intestinal mucosa. Vitamin A modestly improved immune responses to type 1 poliovirus vaccine but did not enhance serum vibriocidal responses to a killed oral cholera vaccine [121]. Two studies investigated zinc supplementation and responses to a non-living oral cholera vaccine; one [121] showed slight improvement of vibriocidal responses following zinc supplementation, whereas the other [122] reported suppression. This suggests that further evaluation of zinc is needed. Alanylglutamine may improve gut integrity in patients with environmental enteropathy [123]. Lastly, modifying the innate immune system of the gut in relation to oral vaccination should be studied with increased stimulation (vaccine plus a mucosal adjuvant such as Escherichia coli double mutant LT [124]) to counteract possible tolerance, or with dampening of the innate immunity (vaccine plus a suppressive agent) to determine which approach, if any, has an ameliorating effect.

Published: 4 October 2010

References

1. Levine MM: The legacy of Edward Jenner. BMJ 1996, 312:1177-1178.
2. Levine MM, Campbell JD, Kotloff KL: Overview of vaccines and immunisation. BrMed Bull 2002, 62:1-13.

3. Whitney CG, Farley MM, Hadler J, Harrison LH, Bennett NM, Lynfield R, Reingold A, Cieslak PR, Pilishvili T, Jackson D, Facklam RR, Jorgensen JH, Schuchat A: Decline in invasive pneumococcal disease after the introduction of protein-polysaccharide conjugate vaccine. N Engl J Med 2003, 348:1737-1746.

4. Sur D, Ochiai RL, Bhattacharya SK, Ganguly NK, Ali M, Manna B, Dutta S, Donner A, Kanungo S, Park JK, Puri MK, Kim DR, Dutta D, Bhaduri B, Acosta CJ, Clemens JD: A cluster-randomized effectiveness trial of Vi typhoid vaccine in India. N Engl J Med2009, 361:335-334.

5. De Quadros CA, Hersh BS, Olive JM, Andrus JK, Da Silveira CM, Carrasco PA: Eradication of wild poliovirus from the Americas: acute flaccid paralysis surveillance, 1988-1995. J Infect Dis 1997, 175 Suppl 1:S37-S42.

6. Strebel PM, Henao-Restrepo AM, Hoekstra E, Olive JM, Papania MJ, Cochi SL: Global measles elimination efforts: the significance of measles elimination in the United States. J Infect Dis 2004, 189 Suppl 1:S251-S257.

7. Peltola H, Jokinen S, Paunio M, Hovi T, Davidkin I: Measles, mumps, and rubella in Finland: 25 years of a nationwide elimination programme. Lancet Infect Dis 2008, 8:796-803.

8. De Quadros CA, Andrus JK, novaro-Holliday MC, Castillo-Solorzano C: Feasibility of global measles eradication after interruption of transmission in the Americas. Expert Rev Vaccines 2008, 7:355-362.

9. Foege WH, Millar JD, Lane JM: Selective epidemiologic control in smallpox eradication. Am J Epidemiol 1971, 94:311-315.

10. Henderson DA: Principles and lessons from the smallpox eradication programme. Bull World Health Organ 1987, 65:535-546.

11. Black RE, Cousens S, Johnson HL, Lawn JE, Rudan I, Bassani DG, Jha P, Campbell H, Walker CF, Cibulskis R, Eisele T, Liu L, Mathers C: Global, regional, and national causes of child mortality in 2008: a systematic analysis. Lancet 2010, 375:1969-1987.

12. Sow SO, Tapia MD, Diallo S, Keita MM, Sylla M, Onwuchekwa U, Pasetti MF, Kotloff KL, Levine MM: Haemophilus influenzae type b conjugate vaccine introduction in Mali: Impact on disease burden and serologic correlate of protection. Am J Trop Med Hyg 2009, 80:1033-1038.

13. Adegbola RA, Secka O, Lahai G, Lloyd-Evans N, Njie A, Usen S, Oluwalana C, Obaro S, Weber M, Corrah T, Mulholland K, McAdam K, Greenwood B, Milligan PJ: Elimination of Haemophilus influenzae type $b(\mathrm{Hib})$ disease from The Gambia after the introduction of routine immunisation with a Hib conjugate vaccine: a prospective study. Lancet 2005, 366:144-150.

14. de Palma O, Cruz L, Ramos H, de BA, Villatoro N, Pastor D, de Oliveira LH, Kerin T, Bowen M, Gentsch J, Esposito DH, Parashar U, Tate J, Patel M: Effectiveness of rotavirus vaccination against childhood diarrhoea in El Salvador: case-control study. BMJ 2010, 340:c2825.

15. Cutts FT, Zaman SMA, Enwere G, Jaffar S, Levine OS, Okoko JB, Oluwalana C, Vaughan A, Obaro SK, Leach A, McAdam KP, Biney E, Saaka M, Onwuchekwa U, Yallop F, Pierce NF, Greenwood BM, Adegbola RA, Gambian Pneumococcal Vaccine Trial Group: Efficacy of nine-valent pneumococcal conjugate vaccine against pneumonia and invasive pneumococcal disease in The Gambia: randomised, double-blind, placebo-controlled trial. Lancet 2005, 365:1139-1146.

16. Kane A, Lloyd J, Zaffran M, Simonsen L, Kane M: Transmission of hepatitis B, hepatitis $C$ and human immunodeficiency viruses through unsafe injections in the developing world: model-based regional estimates. Bull World Health Organ 1999, 77:801-807.

17. Simonsen L, Kane A, Lloyd J, Zaffran M, Kane M: Unsafe injections in the developing world and transmission of bloodborne pathogens: a review. Bull World Health Organ 1999, 77:789-800.

18. Levine MM: Can needle-free administration of vaccines become the norm in global immunization? Nat Med 2003, 9:99-103.

19. Sutter RW, Maher C: Mass vaccination campaigns for polio eradication: an essential strategy for success. Curr Top Microbiol Immunol 2006, 304:195-220.

20. Andrianarivelo MR, Boisier P, Rabarijaona L, Ratsitorahina M, Migliani R, Zeller $\mathrm{H}$ : Mass vaccination campaigns to eradicate poliomyelitis in Madagascar: oral poliovirus vaccine increased immunity of children who missed routine programme. Trop Med Int Health 2001, 6:1032-1039.

21. Robbins FC, De Quadros CA: Certification of the eradication of indigenous transmission of wild poliovirus in the Americas. J Infect Dis 1997, 175 Suppl 1:S281-S285.

22. Smith J, Leke R, Adams A, Tangermann RH: Certification of polio eradication: process and lessons learned. Bull World Health Organ 2004, 82:24-30. 
23. Aylward RB, Linkins J: Polio eradication: mobilizing and managing the human resources. Bull World Health Organ 2005, 83:268-273.

24. Aylward RB, Heymann DL: Can we capitalize on the virtues of vaccines? Insights from the polio eradication initiative. Am J Public Health 2005, 95:773-777.

25. John TJ, Jayabal P: Oral polio vaccination of children in the tropics. I. The poor seroconversion rates and the absence of viral interference. Am $\lrcorner$ Epidemiol 1972, 96:263-269.

26. John TJ: Oral polio vaccination of children in the tropics. II. Antibody response in relation to vaccine virus infection. Am J Epidemiol 1975, 102:414-421.

27. John TJ, Christopher S: Oral polio vaccination of children in the tropics. III. Intercurrent enterovirus infections, vaccine virus take and antibody response. Am J Epidemio/ 1975, 102:422-428.

28. John TJ: Problems with oral poliovaccine in India. Indian Pediatr 1972, 9:252-256.

29. John TJ: Antibody response of infants in tropics to five doses of oral polio vaccine. BrMed J 1976, 1:812

30. John TJ: Immunisation against polioviruses in developing countries. Rev Med Virol 1993, 3:149-160.

31. Patriarca PA, Wright PF, John TJ: Factors affecting the immunogenicity of oral poliovirus vaccine in developing countries: Review. Rev Inf Dis 1991 13:926-929.

32. Vashishtha VM, Kalra A, John TJ, Thacker N, Agarwal RK: Recommendations of 2nd National Consultative Meeting of Indian Academy of Pediatrics (IAP) on polio eradication and improvement of routine immunization. Indian Pediatr 2008, 45:367-378.

33. Paul Y: Why polio has not been eradicated in India despite many remedial interventions? Vaccine 2009, 27:3700-3703.

34. Grassly NC, Fraser C, Wenger J, Deshpande JM, Sutter RW, Heymann DL, Aylward RB: New strategies for the elimination of polio from India. Science 2006, 314:1150-1153

35. World Health Organization: Polio vaccines and polio immunization in the pre-eradication era: WHO position paper. Wkly Epidemiol Rec 2010, 85:213-228.

36. Hanlon P, Hanlon L, Marsh V, Byass P, Shenton F, Hassan-King M, Jobe O, Sillah $H$, Hayes $R$, M'Boge BH: Trial of an attenuated bovine rotavirus vaccine (RIT 4237) in Gambian infants. Lancet 1987, 1:1342-1345.

37. Lanata CF, Midthun K, Black RE, Butron B, Huapaya A, Penny ME, Ventura G, Gil A, Jett-Goheen M, Davidson BL: Safety, immunogenicity, and protective efficacy of one and three doses of the tetravalent rhesus rotavirus vaccine in infants in Lima, Peru. J Infect Dis 1996, 174:268-275.

38. Madhi SA, Cunliffe NA, Steele D, Witte D, Kirsten M, Louw C, Ngwira B, Victor JC, Gillard PH, Cheuvart BB, Han HH, Neuzil KM: Effect of human rotavirus vaccine on severe diarrhea in African infants. N Engl J Med 2010, 362:289-298.

39. Armah GE, Sow SO, Breiman RF, Dallas MJ, Tapia MD, Feikin DR, Binka FN Steele AD, Laserson KF, Ansah A, Levine MM, Lewis K, Coia ML, Attah-Poku M, Ojwando J, Rivers SB, Victor JC, Nyambane G, Hodgson A, Schödel F, Ciarlet M, Neuzil KM: Efficacy of pentavalent human-bovine reassortant rotavirus vaccine against severe rotavirus gastroenteritis in sub-Saharan Africa: a randomized, double-blind, placebo-controlled trial. Lancet 2010, 376:606-614.

40. Mirzayeva R, Steele AD, Parashar UD, Zaman K, Neuzil KM, Nelson EA: Evaluation of rotavirus vaccines in Asia - are there lessons to be learnt? Vaccine 2009, 27 Suppl 5:F120-F129.

41. Suharyono, Simanjuntak C, Witham N, Punjabi N, Heppner DG, Losonsky G, Totosudirjo H, Rifai AR, Clemens J, Lim YL, Burr D, Wasserman SS, Kaper J, Sorenson K, Cryz S, Levine MM: Safety and immunogenicity of single-dose live oral cholera vaccine CVD 103-HgR in 5-9-year-old Indonesian children. Lancet 1992, 340:689-694

42. Su-Arehawaratana P, Singharaj P, Taylor DN, Hoge C, Trofa A, Kuvanont K, Migasena S, Pitisuttitham P, Lim YL, Losonsky G, Kaper JB, Wasserman SS, Cryz S, Echeverria P, Levine MM: Safety and immunogenicity of different immunization regimens of CVD 103-HgR live oral cholera vaccine in soldiers and civilians in Thailand. J Infect Dis 1992, 165:1042-1048.

43. Gotuzzo E, Butron B, Seas C, Penny M, Ruiz R, Losonsky G, Lanata CF, Wasserman SS, Salazar E, Kaper JB, Cryz S, Levine M: Safety, immunogenicity, and excretion pattern of single-dose live oral cholera vaccine CVD 103-HgR in Peruvian adults of high and low socioeconomic levels. Infect Immun 1993, 61:3994-3997.
44. Lagos R, Fasano A, Wasserman SS, Prado V, San Martin O, Abrego P, Losonsky $G A$, Alegria S, Levine MM: Effect of small bowel bacterial overgrowth on the immunogenicity of single-dose live oral cholera vaccine CVD 103-HgR. J Infect Dis 1999, 180:1709-1712.

45. Hallander HO, Paniagua M, Espinoza F, Askelof P, Corrales E, Ringman M, Storsaeter J: Calibrated serological techniques demonstrate significant different serum response rates to an oral killed cholera vaccine between Swedish and Nicaraguan children. Vaccine 2002, 21:138-145

46. Levine MM, Kotloff KL, Barry EM, Pasetti MF, Sztein MB: Clinical trials of Shigella vaccines: two steps forward and one step back on a long, hard road. Nat Rev Microbiol 2007, 5:540-553.

47. World Health Organization: Future needs and directions for Shigella vaccines. Wkly Epidemiol Rec 2006, 81:51-58.

48. Brandtzaeg P: The mucosal immune system and its integration with the mammary glands. J Pediatr 2010, 156:S8-15.

49. Walker A: Breast milk as the gold standard for protective nutrients. J Pediatr 2010, 156:S3-S7.

50. Giugliano LG, Ribeiro ST, Vainstein $M H$, Ulhoa CJ: Free secretory component and lactoferrin of human milk inhibit the adhesion of enterotoxigenic Escherichia coli. J Med Microbiol 1995, 42:3-9.

51. Kunz C, Rudloff S: Potential anti-inflammatory and anti-infectious effects of human milk oligosaccharides. Adv Exp Med Bio/ 2008, 606:455-465.

52. Linhares AC, Bresee JS: Rotavirus vaccines and vaccination in Latin America. Rev Panam Salud Publica 2000, 8:305-331.

53. Ruiz-Palacios GM, Perez-Schael I, Velazquez FR, Abate H, Breuer T, Clemens SC, Cheuvart B, Espinoza F, Gillard P, Innis BL, Cervantes Y, Linhares AC, Lopez P, ias-Parra M, Ortega-Barria E, Richardson V, Rivera-Medina DM, Rivera L, Salinas B, Pavia-Ruz N, Salmeron J, Ruttimann R, Tinoco JC, Rubio P, Nunez E, Guerrero ML, Yarzabal JP, Damaso S, Tornieporth N, Saez-Llorens X, et al.: Safety and efficacy of an attenuated vaccine against severe rotavirus gastroenteritis. NEngl J Med 2006, 354:11-22.

54. Vesikari T, Matson DO, Dennehy P, Van DP, Santosham M, Rodriguez Z, Dallas MJ, Heyse JF, Goveia MG, Black SB, Shinefield HR, Christie CD, Ylitalo S, Itzler RF, Coia ML, Onorato MT, Adeyi BA, Marshall GS, Gothefors L, Campens D, Karvonen A, Watt JP, O'Brien KL, DiNubile MJ, Clark HF, Boslego JW, Offit PA, Heaton PM: Safety and efficacy of a pentavalent human-bovine (WC3) reassortant rotavirus vaccine. N Engl J Med 2006, 354:23-33.

55. Levine MM, Kaper JB: Live oral vaccines against cholera: an update. Vaccine 1993, 11:207-212.

56. Levine MM, Kaper JB: Live oral cholera vaccine: from principle to product. Bull Inst Pasteur 1995, 93:243-253.

57. Ketley JM, Michalski J, Galen J, Levine MM, Kaper JB: Construction of genetically marked Vibrio cholerae 01 vaccine strains. FEMS Microbio/ Lett 1993, 111:15-21.

58. Kotloff KL, Wasserman SS, O'Donnell S, Losonsky GA, Cryz SJ, Levine MM: Safety and immunogenicity in North Americans of a single dose of live oral cholera vaccine CVD 103-HgR: Results of a randomized, placebocontrolled, double-blind crossover trial. Infect Immun 1992, 60:4430-4432.

59. Levine MM, Kaper JB, Herrington D, Ketley J, Losonsky G, Tacket CO, Tall B, Cryz S: Safety, immunogenicity, and efficacy of recombinant live oral cholera vaccines, CVD 103 and CVD 103-HgR. Lancet 1988, 2:467-470.

60. Tacket CO, Losonsky G, Nataro JP, Cryz SJ, Edelman R, Kaper JB, Levine MM: Onset and duration of protective immunity in challenged volunteers after vaccination with live oral cholera vaccine CVD 103-HgR. J Infect Dis 1992, 166:837-841.

61. Tacket CO, Cohen MB, Wasserman SS, Losonsky G, Livio S, Kotloff K, Edelman R, Kaper JB, Cryz SJ, Giannella RA, Schiff G, Levine MM: Randomized, doubleblind, placebo-controlled, multicentered trial of the efficacy of a single dose of live oral cholera vaccine CVD 103-HgR in preventing cholera following challenge with vibrio cholerae $01 \mathrm{El}$ tor Inaba three months after vaccination. Infect Immun 1999, 67:6341-6345.

62. Migasena S, Pitisuttitham P, Prayurahong P, Suntharasami P, Supanaranond W, Desakorn V, Vongsthongsri U, Tall B, Ketley J, Losonsky G, Cryz S, Kaper JB, Levine MM: Preliminary assessment of the safety and immunogenicity of live oral cholera vaccine strain CVD 103-HgR in healthy Thai adults. Infect Immun 1989, 57:3261-326463. Cryz SJ, Levine MM, Kaper JB, Furer E, Althaus B: Randomized double-blind placebo controlled trial to evaluate the safety and immunogenicity of the live oral cholera vaccine strain CVD 103-HgR in Swiss adults. Vaccine 1990, 8:577-580

64. Simanjuntak CH, O'Hanley P, Punjabi NH, Noriega F, Pazzaglia G, Dykstra P, Kay B, Suharyono, Budiarso A, Rifai A, Wasserman SS, Losonsky GA, Kaper J, Cryz S, 
Levine MM: The safety, immunogenicity, and transmissibility of singledose live oral cholera vaccine CVD 103-HgR in 24 to 59 month old Indonesian children. J Infect Dis 1993, 168:1169-1176.

65. Lagos R, Avendano A, Horwitz I, Prado V, Ferreccio C, Losonsky G, Wasserman SS, Cryz S, Kaper JB, Levine MM: Tolerancia e inmunogenicidad de una dosis oral de la cepa de Vibrio cholerae 01, viva-atenuada, CVD 103-HgR: estudio de doble ciego en adultos Chilenos. Rev Med Chile 1993, 121:857-863.

66. Lagos R, Avendano A, Prado V, Horwitz I, Wasserman SS, Losonsky G, Cryz JrSC, Kaper JB, Levine MM: Attenuated live oral cholera vaccine strain CVD 103-HgR elicits significantly higher serum vibriocidal antibody titers in persons of blood group O. Infect Immun 1995, 63:707-709.

67. Lagos R, Losonsky G, Abrego P, San Martin O, Prado V, Wasserman S, Levine MM: Tolerancia, immunogenicidad, excresión y transmisión de la vacuna anticolera oral viva-atenuada, CVD 103-HgR, estudio pareado de doble ciego en niños Chilenos de 24 a 59 meses. Bol Hosp Infant Mex 1996, 53:214-220.

68. Lagos R, San Martin O, Wasserman SS, Prado V, Losonsky GA, Bustamante C, Levine MM: Palatability, reactogenicity and immunogenicity of engineered live oral cholera vaccine CVD 103-HgR in Chilean infants and toddlers. Pediatr Infect Dis J 1999, 18:624-630.

69. Wasserman SS, Losonsky GA, Noriega F, Tacket CO, Castaneda E, Levine MM: Kinetics of the vibriocidal antibody response to live oral cholera vaccines. Vaccine 1994, 12:1000-1003.

70. Perry RT, Plowe CV, Koumaré B, Kotloff KL, Losonsky GA, Wasserman SS, Levine MM: A single dose of live oral cholera vaccine CVD 103-HgR is safe and immunogenic in HIV-infected and non-infected adults in Mali. Bull WId Hlth Org 1998, 76:63-71.

71. Glass RI, Holmgren J, Haley CE, Khan MR, Svennerholm AM, Stoll BJ, Belayet Hossain KM, Black RE, Yunus M, Barua D: Predisposition for cholera of individuals with $\mathrm{O}$ blood group. Possible evolutionary significance. Am J Epidemiol 1985, 121:791-796.

72. Tacket CO, Losonsky G, Nataro JP, Wasserman SS, Cryz SJ, Edelman R, Levine MM: Extension of the volunteer challenge model to study South American cholera in a population of volunteers predominantly with blood group antigen O. Trans R Soc Trop Med Hyg 1995, 89:75-77.

73. Fagundes-Neto U, Viaro T, Wehba J, Patricio FR, Machado NL: Tropical enteropathy (environmental enteropathy) in early childhood: a syndrome caused by contaminated environment. J Trop Pediatr 1984, 30:204-209.

74. Fagundes Neto U, Martins MC, Lima FL, Patricio FR, Toledo MR: Asymptomatic environmental enteropathy among slum-dwelling infants. J Am Coll Nutr 1994, 13:51-56

75. Cooper PJ, Chico ME, Losonsky G, Sandoval C, Espinel I, Sridhara R, Aguilar M, Guevara A, Guderian RH, Levine MM, Griffin GE, Nutman TB: Albendazole treatment of children with ascariasis enhances the vibriocidal antibody response to the live attenuated oral cholera vaccine CVD 103-HgR. J Infect Dis 2000, 182:1199-1206.

76. Cooper PJ, Chico M, Sandoval C, Espinel I, Guevara A, Levine MM, Griffin GE, Nutman TB: Human infection with Ascaris lumbricoides is associated with suppression of the interleukin-2 response to recombinant cholera toxin B subunit following vaccination with the live oral cholera vaccine CVD 103-HgR. Infect Immun 2001, 69:1574-1580.

77. Anderson CM, Langford RF: Bacterial content of small intestine of children in health, in coeliac disease, and in fibrocystic disease of pancreas. Br Med J 1958, 1:803-806.

78. Ou G, Hedberg M, Horstedt P, Baranov V, Forsberg G, Drobni M, Sandstrom O, Wai SN, Johansson I, Hammarstrom ML, Hernell O, Hammarstrom S: Proximal small intestinal microbiota and identification of rod-shaped bacteria associated with childhood celiac disease. Am J Gastroenterol 2009, 104:3058-3067.

79. Khin-Maung-U, Bolin TD, Duncombe VM, Myo-Khin, Nyunt-Nyunt-Wai, Pereira SP, Linklater JM: Epidemiology of small bowel bacterial overgrowth and rice carbohydrate malabsorption in Burmese (Myanmar) village children. Am J Trop Med Hyg 1992, 47:298-304.

80. dos Reis JC, de Morais MB, Oliva CA, Fagundes-Neto U: Breath hydrogen test in the diagnosis of environmental enteropathy in children living in an urban slum. Dig Dis Sci 2007, 52:1253-1258.

81. Salazar-Lindo E, Allen S, Brewster DR, Elliott EJ, Fasano A, Phillips AD, Sanderson IR, Tarr PI: Intestinal infections and environmental enteropathy: Working Group report of the second World Congress of Pediatric Gastroenterology, Hepatology, and Nutrition. J Pediatr Gastroenterol Nutr 2004, 39 Suppl 2:S662-S669.

82. Lindenbaum J, Gerson CD, Kent TH: Recovery of small-intestinal structure and function after residence in the tropics. I. Studies in Peace Corps volunteers. Ann Intern Med 1971, 74:218-222.

83. Pereira SP, Khin-Maung-U, Bolin TD, Duncombe VM, Nyunt-Nyunt-Wai, Myo-Khin, Linklater JM: A pattern of breath hydrogen excretion suggesting small bowel bacterial overgrowth in Burmese village children. J Pediatr Gastroenterol Nutr 1991, 13:32-38.

84. Shedlofsky S, Freter R: Synergism between ecologic and immunologic control mechanisms of intestinal flora. J Infect Dis 1974, 129:296-303.

85. Silva SH, Vieira EC, Dias RS, Nicoli JR: Antagonism against Vibrio cholerae by diffusible substances produced by bacterial components of the human faecal microbiota. J Med Microbiol 2001, 50:161-164

86. Veitch AM, Kelly P, Zulu IS, Segal I, Farthing MJ: Tropical enteropathy: a T-cellmediated crypt hyperplastic enteropathy. Eur J Gastroenterol Hepatol 2001, 13:1175-1181

87. Neish AS: Microbes in gastrointestinal health and disease. Gastroenterol 2009, 136:65-80

88. Srikanth CV, McCormick BA: Interactions of the intestinal epithelium with the pathogen and the indigenous microbiota: a three-way crosstalk. Interdiscip Perspect Infect Dis 2008, 2008:626827

89. Shi HN, Walker A: Bacterial colonization and the development of intestinal defences. Can J Gastroenterol 2004, 18:493-500.

90. Salzman NH, Hung K, Haribhai D, Chu H, Karlsson-Sjoberg J, Amir E, Teggatz P, Barman M, Hayward M, Eastwood D, Stoel M, Zhou Y, Sodergren E, Weinstock GM, Bevins CL, Williams CB, Bos NA: Enteric defensins are essential regulators of intestinal microbial ecology. Nat Immunol 2010, 11:76-83.

91. Artis D: Epithelial-cell recognition of commensal bacteria and maintenance of immune homeostasis in the gut. Nat Rev Immuno/ 2008, 8:411-420.

92. Mowat AM: Anatomical basis of tolerance and immunity to intestinal antigens. Nat Rev Immunol 2003, 3:331-341

93. Campbell DI, Murch SH, Elia M, Sullivan PB, Sanyang MS, Jobarteh B, Lunn PG Chronic T cell-mediated enteropathy in rural west African children: relationship with nutritional status and small bowel function. Pediatr Res 2003, 54:306-311.

94. Strachan DP: Family size, infection and atopy: the first decade of the "hygiene hypothesis". Thorax 2000, 55 Suppl 1:S2-10::S2-10.

95. Bloomfield SF, Stanwell-Smith R, Crevel RW, Pickup J: Too clean, or not too clean: the hygiene hypothesis and home hygiene. Clin Exp Allergy 2006, 36:402-425.

96. Bickler SW: Tropical enteropathy protects against Western diseases in environments of poor sanitation. Med Hypotheses 2006, 67:146-150.

97. Coster TS, Hoge CW, VanDeVerg LL, Hartman AB, Oaks EV, Venkatesan MM, Cohen D, Robin G, Fontaine-Thompson A, Sansonetti PJ, Hale TL: Vaccination against shigellosis with attenuated Shigella flexneri 2a strain SC602. Infect Immun 1999, 67:3437-3443.

98. Levine MM, Ferreccio C, Black RE, Tacket CO, Germanier R: Progress in vaccines against typhoid fever. Rev Infect Dis 1989, 11 Suppl 3:S552-S567.

99. Viret JF, Favre D, Wegmuller B, Herzog C, Que JU, Cryz SJ Jr, Lang AB: Mucosal and systemic immune responses in humans after primary and booster immunizations with orally administered invasive and noninvasive live attenuated bacteria. Infect Immun 1999, 67:3680-3685.

100. D'Amelio R, Tagliabue A, Nencioni L, DiAddario A, Villa L, Manganaro M, Boraschi D, Le Moli S, Nisini R, Matricardi PM: Comparative analysis of immunological responses to oral (Ty21a) and parenteral (TAB) typhoid vaccines. Infect Immun 1988, 56:2731-2735.

101. Kantele A, Kantele JM, Savilahti E, Westerholm M, Arvilommi H, Lazarovits A, Butcher EC, Makela PH: Homing potentials of circulating lymphocytes in humans depend on the site of activation: oral, but not parenteral, typhoid vaccination induces circulating antibody-secreting cells that all bear homing receptors directing them to the gut. J Immuno/ 1997, 158:574-579.

102. Salerno-Goncalves R, Pasetti MF, Sztein MB: Characterization of CD8(+) effector $T$ cell responses in volunteers immunized with Salmonella enterica serovar Typhi strain Ty21a typhoid vaccine. J Immunol 2002, 169:2196-2203.

103. Salerno-Goncalves R, Wahid R, Sztein MB: Immunization of volunteers with Salmonella enterica serovar Typhi strain Ty21a elicits the oligoclonal expansion of CD8+ T cells with predominant Vbeta repertoires. Infect Immun 2005, 73:3521-3530.

104. Lundin BS, Johansson C, Svennerholm AM: Oral immunization with a Salmonella enterica serovar Typhi vaccine induces specific circulating mucosa-homing CD4(+) and CD8(+) T cells in humans. Infect Immun 2002, 
70:5622-5627.

105. Salerno-Goncalves $R$, Wyant TL, Pasetti MF, Fernandez-Vina M, Tacket CO, Levine MM, Sztein MB: Concomitant induction of CD4(+) and CD8(+) T cell responses in volunteers immunized with Salmonella enterica serovar Typhi strain CVD 908-htrA. J Immunol 2003, 170:2734-2741.

106. Wahdan MH, Serie C, Cerisier Y, Sallam S, Germanier R: A controlled field trial of live Salmonella typhi strain Ty21a oral vaccine against typhoid: Three year results. J Infect Dis 1982, 145:292-296.

107. Levine MM, Ferreccio C, Black RE, Germanier R, Chilean Typhoid Committee: Large-scale field trial of Ty21a live oral typhoid vaccine in enteric-coated capsule formulation. Lancet 1987, 1:1049-1052

108. Black RE, Levine MM, Ferreccio C, Clements ML, Lanata C, Rooney J, Germanier R: Efficacy of one or two doses of Ty21a Salmonella typhi vaccine in enteric-coated capsules in a controlled field trial. Chilean Typhoid Committee. Vaccine 1990, 8:81-84.

109. Levine MM, Ferreccio C, Cryz S, Ortiz E: Comparison of enteric-coated capsules and liquid formulation of Ty21a typhoid vaccine in randomised controlled field trial. Lancet 1990, 336:891-894.

110. Levine MM, Ferreccio C, Abrego P, Martin OS, Ortiz E, Cryz S: Duration of efficacy of ty $21 \mathrm{a}$, attenuated salmonella typhi live oral vaccine. Vaccine 1999, 17 Suppl 2:S22-S27.

111. Simanjuntak C, Paleologo F, Punjabi N, Darmowitogo R, Soeprawato, Totosudirjo H, Haryanto P, Suprijanto E, Witham N, Hoffman SL: Oral immunisation against typhoid fever in Indonesia with Ty21a vaccine. Lancet 1991, 338:1055-1059.

112. Kohbata S, Yokoyama H, Yabuchi E: Cytopathogenic effect of Salmonella typhi GIFU 10007 on M cells of murine ileal Peyer's patches in ligated ileal loops: an ultrastructural study. Microbiol Immunol 1986, 30:1225-1237.

113. Neutra MR, Frey A, Kraehenbuhl JP: Epithelial M cells: gateways for mucosal infection and immunization. Cell 1996, 86:345-348.

114. Tacket CO, Sztein MB, Wasserman SS, Losonsky G, Kotloff KL, Wyant TL, Nataro JP, Edelman R, Perry J, Bedford P, Brown D, Chatfield S, Dougan G, Levine MM: Phase 2 clinical trial of attenuated Salmonella enterica serovar Typhi oral live vector vaccine CVD 908-htrA in U.S. volunteers. Infect Immun 2000, 68:1196-1201.

115. Tacket CO, Pasetti MF, Sztein MB, Livio S, Levine MM: Immune responses to an oral typhoid vaccine strain that is modified to constitutively express $\mathrm{Vi}$ capsular polysaccharide. J Infect Dis 2004, 190:565-570

116. Kirkpatrick BD, McKenzie R, O'Neill JP, Larsson CJ, Bourgeois AL, Shimko J, Bentley M, Makin J, Chatfield S, Hindle Z, Fidler C, Robinson BE, Ventrone CH, Bansal N, Carpenter CM, Kutzko D, Hamlet S, LaPointe C, Taylor DN: Evaluation of Salmonella enterica serovar Typhi (Ty2 aroC-ssaV-) M01ZH09, with a defined mutation in the Salmonella pathogenicity island 2, as a live, oral typhoid vaccine in human volunteers. Vaccine 2006, 24:1 16-123.
117. Tran $T H$, Nguyen TD, Nguyen $T T$, Ninh TT, Tran NB, Nguyen VM, Tran TT, Cao TT, Pham VM, Nguyen TC, Tran TD, Pham VT, To SD, Campbell Jl, Stockwell E, Schultsz C, Simmons CP, Glover C, Lam W, Marques F, May JP, Upton A, Budhram R, Dougan G, Farrar J, Nguyen W, Dolecek C: A randomised trial evaluating the safety and immunogenicity of the novel single oral dose typhoid vaccine M01ZH09 in healthy Vietnamese children. PLOS ONE 2010 5:e11778

118. Czerkinsky C, Holmgren J: Enteric vaccines for the developing world: a challenge for mucosal immunology. Mucosal Immunol 2009, 2:284-287.

119. Trehan I, Shulman RJ, Ou CN, Maleta K, Manary MJ: A randomized, doubleblind, placebo-controlled trial of rifaximin, a nonabsorbable antibiotic, in the treatment of tropical enteropathy. Am J Gastroenterol 2009, 104:2326-2333.

120. Hollm-Delgado MG, Gilman RH, Bern C, Cabrera L, Sterling CR, Black RE, Checkley W: Lack of an adverse effect of Giardia intestinalis infection on the health of Peruvian children. Am J Epidemiol 2008, 168:647-655.

121. Albert MJ, Qadri F, Wahed MA, Ahmed T, Rahman AS, Ahmed F, Bhuiyan NA, Zaman K, Baqui AH, Clemens JD, Black RE: Supplementation with zinc, but not vitamin $A$, improves seroconversion to vibriocidal antibody in children given an oral cholera vaccine. J Infect Dis 2003, 187:909-913.

122. Qadri F, Ahmed T, Wahed MA, Ahmed F, Bhuiyan NA, Rahman AS, Clemens JD, Black RE, Albert MJ: Suppressive effect of zinc on antibody response to cholera toxin in children given the killed, B subunit-whole cell, oral cholera vaccine. Vaccine 2004, 22:416-421.

123. Lima NL, Soares AM, Mota RM, Monteiro HS, Guerrant RL, Lima AA: Wasting and intestinal barrier function in children taking alanyl-glutaminesupplemented enteral formula. J Pediatr Gastroenterol Nutr 2007, 44:365-374.

124. Summerton NA, Welch RW, Bondoc L, Yang HH, Pleune B, Ramachandran N, Harris AM, Bland D, Jackson WJ, Park S, Clements JD, Nabors GS: Toward the development of a stable, freeze-dried formulation of Helicobacter pylori killed whole cell vaccine adjuvanted with a novel mutant of Escherichia coli heat-labile toxin. Vaccine 2010, 28:1404-1411.

125. Linhares AC, Gabbay YB, Mascarenhas JD, de Freitas RB, Oliveira CS, Bellesi N, Monteiro TA, Lins-Lainson Z, Ramos FL, Valente SA: Immunogenicity, safety and efficacy of tetravalent rhesus-human, reassortant rotavirus vaccine in Belem, Brazil. Bull World Health Organ 1996, 74:491-500.

doi:10.1186/1741-7007-8-129

Cite this article as: Levine MM: Immunogenicity and efficacy of oral vaccines in developing countries: lessons from a live cholera vaccine. BMC Biology 2010, 8:129. 